\title{
Apparent low frequency of undernutrition in Dublin hospital in-patients: should we review the anthropometric thresholds for clinical practice?
}

\author{
Clare A. Corish*, P. Flood, S. Mulligan and N. P. Kennedy \\ Unit of Nutrition and Dietetic Studies, Department of Clinical Medicine, Trinity Centre for Health Sciences, \\ James's St, Dublin 8, Republic of Ireland
}

(Received 7 May 1999 - Revised 10 January 2000 - Accepted 14 January 2000)

\begin{abstract}
Protein-energy undernutrition, or the possibility of its development, has been documented to occur frequently in patients on admission to hospital. Deterioration in nutritional status is known to occur in hospital. In a prospective study of 594 sequential hospital admissions, we aimed to assess the prevalence of undernutrition among patients on admission to two acute teaching hospitals in Dublin, Republic of Ireland using the widely-accepted anthropometric criteria applied in a large study from Dundee, Scotland, UK (McWhirter \& Pennington, 1994) and to determine changes in nutritional status in hospital. The mean prevalence of undernutrition $(11 \%)$ was considerably lower than was reported from Dundee (40\%). Unintentional weight loss before admission and functional impairment on admission occurred to a similar extent in both centres. Weight loss in hospital occurred in the same proportion of patients, but less frequently among those undernourished on admission to hospital, in Dublin compared with Dundee. The patients found to be undernourished on admission in this study had a mortality rate in hospital $(6.5 \%)$ over three times that of the adequately nourished group $(2 \%)$. The magnitude of the difference in prevalence of undernutrition between the two centres cannot be explained by ethnicity, case-mix or age distribution. With the secular increase in BMI in the population, the thresholds for classifying patients as undernourished or at risk of nutritional deterioration may need to be reviewed. For clinical use, recent weight loss and functional status may be more appropriate variables to use in the evaluation of nutritional status on admission to hospital.
\end{abstract}

Undernutrition: Anthropometry: Reference data

The deleterious effects of impaired nutritional status on clinical outcome (Gallagher-Allred et al. 1996; Giner et al. 1996; Lumbers et al. 1996) and hospital costs (Tucker \& Miguel, 1996) are widely acknowledged. If undernutrition is adequately documented on hospital admission and appropriate nutrition therapy is initiated, an improvement in clinical outcome should be expected. Protein-energy undernutrition, or the possibility of its development, has been documented to occur frequently in patients on admission to hospital (Butterworth, 1974; Bistrian et al. 1976; Hill et al. 1977; McWhirter \& Pennington, 1994; Naber et al. 1997; Gariballa et al. 1998). However, these studies examined specific patient groups and employed a number of different definitions of undernutrition. As a result, direct comparison between the published studies and current assessment of the overall prevalence of undernutrition on admission to hospital is difficult.

Many studies assessing the prevalence of undernutrition have been criticised as they based their results on formulas which included biochemical measurement of serum proteins (Bistrian et al. 1976; Hill et al. 1977; Coats et al. 1993;
Veterans Affairs Total Parenteral Nutrition Co-operative Study Group, 1991; Naber et al. 1997), for example, albumin, which may reflect either disease severity or nutritional status. The use of serum proteins may lead to inaccuracy in the estimation of prevalence of undernutrition in sick patients as many patients have reduced levels as a result of their disease, although they would not be classified as undernourished if an alternative method of classification were used. Although many believe that anthropometric criteria can define nutritional status more accurately, the reference data available to define nutritional status do not always reflect the normal distribution of the local healthy population (McWhirter \& Pennington, 1994). The lack of such local reference material may make interpretation of the estimates of undernutrition more difficult. The reference data in current use in the UK and Republic of Ireland were derived from measurements made in the early 1970s of healthy Caucasian Americans (Bishop et al. 1981; Frisancho, 1981) while reference data derived from subjects in South Wales in the UK, published in 1984, are frequently used for defining the nutritional status of those aged 65 years 
or more (Burr \& Phillips, 1984). Considerable geographical variation in anthropometric variables has been observed (Bishop et al. 1981; Frisancho, 1981; Burr \& Phillips, 1984; Delarue et al. 1994; Launer \& Harris, 1996; Bannerman et al. 1997; Rea et al. 1997). Whereas for survey purposes, the use of standard data allow the rates of obesity and underweight to be estimated in different areas of the world and for secular changes to be monitored, for clinical purposes, reference to local, healthy population data may be more appropriate. Although the standard cut-off values for categorising underweight are based on physiological and medical correlates, these do not consider recent weight loss. In ill patients recent weight loss is also correlated with undernutrition-related-complications, which are, in turn, linked to poor outcome. Therefore, the criterion of BMI $<20 \mathrm{~kg} / \mathrm{m}^{2}$, widely used in clinical practice, may not always detect those patients at risk of undernutrition-related-complications, for example, patients of high initial body weights who have lost weight (Stack et al. 1996) or different ethnic (Norgan, 1994; Launer \& Harris, 1996) or age groups (World Health Organization, 1995; Zemel et al. 1997). With the secular increase in adult BMI, the cut-off values at which patients are considered to be at nutritional risk may have to be reviewed (e.g. BMI $<22 \mathrm{~kg} / \mathrm{m}^{2}$ was observed to be a significant predictor of mortality in older Italian people living in the community (Landi et al. 1999) while in the USA, the BMI at which the elderly are now considered at nutritional risk is now defined as $24 \mathrm{~kg} / \mathrm{m}^{2}$ ).

The aims of this study were, first, to measure the prevalence of undernutrition among medical and surgical patients admitted to two teaching hospitals in Dublin, Republic of Ireland, using the same anthropometric criteria as were used in a large study from Dundee, Scotland, UK (McWhirter \& Pennington, 1994) and, second, to determine changes in nutritional status during the hospital stay. The results of the survey were intended to provide a background for planning the resources needed for effective nutritional care in the study hospitals.

\section{Patients and methods}

During an 8-month period, including a summer (1996) and a winter (1996-7) season, data were collected from every 10th and 3rd patient respectively admitted to a larger $(812$ beds) and a smaller (275 beds) Dublin teaching hospital, both with busy Accident and Emergency units and on active call every second day. The list of patient names was obtained from computerised admission records on a daily basis. All patients were assessed within $48 \mathrm{~h}$ of admission. Acute admissions to the special care units in either hospital were excluded, such as Intensive Care, Coronary Care, Burns and Bone Marrow Transplant Units. This was because such patients are generally well nourished on admission to hospital and assessment of their anthropometric status is difficult or impossible. Patients admitted to day wards and children under the age of 16 years were also omitted. Patients were excluded from the analysis of both admission ( $n$ 25) and discharge ( $n$ 16) data if gross fluid retention had been documented or if BMI was not calculable. In order to use the criteria for undernutrition devised by McWhirter \& Pennington (1994), both BMI and upper-arm anthropometry must be measured. Of the twenty-five patients omitted from the analysis, six may have been undernourished, as five had a mid-arm muscle circumference or triceps skinfold thickness between the 5th and 15 th percentile, and one had a midarm muscle circumference or triceps skinfold thickness below the 5th percentile. However, the inclusion of these six patients in the undernourished group would not have altered the overall prevalence of undernutrition in our study. Of 594 patients assessed, 569 were analysed to estimate the prevalence of undernutrition on admission. This represented $7.6 \%$ of total admissions during the recruitment periods in the larger hospital, and $15.3 \%$ in the smaller hospital. Of the 760 patients picked for inclusion, $10(1.3 \%)$ patients refused, $117(15.3 \%)$ were discharged before they could be assessed, $29(3.8 \%)$ could not be assessed within the first 48 hours of their admission, $7(0.9 \%)$ were picked for a second time and $3(0.4 \%)$ died before they could be assessed. The distribution between specialities of patients recruited in this study was comparable to that of patients admitted throughout the previous year, suggesting that the sample was representative of the usual admission profile. Table 1 shows the admission details of the patients studied. Follow-up data were available on discharge from 218 (71\%) of those staying in hospital for a minimum of $7 \mathrm{~d}$. These patients were not pre-selected. Every attempt was made to reassess as many patients as possible by liaison with medical, nursing, dietetic and secretarial staff. Despite this, $21 \%$ of patients were discharged before a second assessment could be carried out. The remaining $8 \%$ of patients died in hospital and were therefore not reassessed. The data were analysed from 202 of these patients to determine the extent of change in nutritional status during the hospital stay. In the sixteen cases omitted from the discharge analysis, BMI could not be calculated or gross fluid retention was documented.

Written informed consent was obtained before measurements were made, and ethical approval was obtained from the joint research ethics committee of St. James's and the Federated Dublin Voluntary Hospitals.

The current nutritional status of the subjects was classified as normal, mildly, moderately or severely undernourished, overweight or obese. Patients were considered to be mildly undernourished if their BMI was less than $20 \mathrm{~kg} / \mathrm{m}^{2}$ and if their triceps skinfold thickness or mid-arm muscle circumference was below the 15th percentile. A BMI of less than $18 \mathrm{~kg} / \mathrm{m}^{2}$ and a triceps skinfold thickness or mid-arm muscle circumference below the 5 th percentile were evidence of moderate undernutrition, and a BMI of less than $16 \mathrm{~kg} / \mathrm{m}^{2}$ and a triceps skinfold thickness or mid-arm muscle circumference below the 5th percentile were evidence of severe undernutrition (McWhirter \& Pennington, 1994).

Height was measured with a Leicester portable stadiometer (Chasmors Weighing Equipment Ltd, London, UK). If height could not be measured ( $n$ 95), stature was calculated from knee height using the equations devised by Chumlea (Chumlea et al. 1985). Weight was measured with highspecification portable scales (Chasmors Weighing Equipment Ltd) which was regularly checked against two others of similar make. No re-calibration of the scales was required during the study period. Patients who could not stand were weighed on mechanical chair scales (calibrated 
Table 1. Details of patients admitted to hospital in Dundee, Scotland, UK and Dublin, Republic of Ireland

\begin{tabular}{|c|c|c|c|c|c|c|c|c|c|}
\hline & \multicolumn{3}{|c|}{ Elective procedures } & \multicolumn{3}{|c|}{ Non-elective procedures } & \multicolumn{3}{|c|}{ Total } \\
\hline & \multirow{2}{*}{$\frac{\text { Dundee }}{n}$} & \multicolumn{2}{|c|}{ Dublin } & \multirow{2}{*}{$\frac{\text { Dundee }}{n}$} & \multicolumn{2}{|c|}{ Dublin } & \multirow{2}{*}{$\frac{\text { Dundee }}{n}$} & \multicolumn{2}{|c|}{ Dublin } \\
\hline & & $n$ & $\%$ & & $n$ & $\%$ & & $n$ & $\%$ \\
\hline General medicine: & 47 & 38 & 19 & 53 & 160 & 81 & 100 & 198 & 100 \\
\hline Ischaemic heart disease & 8 & 4 & & 21 & 26 & & 29 & 30 & 15 \\
\hline Malignant disease & 11 & 18 & & 2 & 21 & & 13 & 39 & 20 \\
\hline Neurological disorders & 3 & 3 & & 9 & 16 & & 12 & 19 & 10 \\
\hline Inflammatory bowel disease & 9 & 1 & & 4 & 1 & & 13 & 2 & 1 \\
\hline Other gastrointestinal disorders & 7 & 2 & & 4 & 20 & & 11 & 22 & 11 \\
\hline Diabetes mellitus & 0 & 2 & & 3 & 3 & & 3 & 5 & 2 \\
\hline Vascular disease & 5 & 1 & & 5 & 23 & & 10 & 24 & 12 \\
\hline Protein-energy malnutrition & 1 & 0 & & 2 & 1 & & 3 & 1 & 0.5 \\
\hline Investigation of weight loss & 2 & 1 & & 0 & 1 & & 2 & 2 & 1 \\
\hline Renal failure & 1 & 1 & & 3 & 3 & & 4 & 4 & 2 \\
\hline Congestive cardiac failure & 0 & 0 & & 0 & 8 & & 0 & 8 & 4 \\
\hline Haematological disorders & 0 & 0 & & 0 & 1 & & 0 & 1 & 0.5 \\
\hline Fevers of unknown origin & 0 & 0 & & 0 & 4 & & 0 & 4 & 2 \\
\hline Drug overdose & 0 & 0 & & 0 & 4 & & 0 & 4 & 2 \\
\hline Psychiatric disorders & 0 & 1 & & 0 & 9 & & 0 & 10 & 5 \\
\hline Acquired immune deficiency syndrome & 0 & 0 & & 0 & 5 & & 0 & 5 & 2 \\
\hline Others & 0 & 4 & & 0 & 14 & & 0 & 18 & 9 \\
\hline Respiratory medicine: & 38 & 5 & 8 & 62 & 55 & 92 & 100 & 60 & 100 \\
\hline Chronic obstructive pulmonary disease & 6 & 0 & & 32 & 23 & & 38 & 23 & 38 \\
\hline Asthma & 7 & 0 & & 11 & 4 & & 18 & 4 & 7 \\
\hline Malignant disease & 12 & 3 & & 0 & 7 & & 12 & 10 & 17 \\
\hline Tuberculosis & 3 & 0 & & 0 & 0 & & 3 & 0 & \\
\hline Trauma & 0 & 0 & & 3 & 1 & & 3 & 1 & 2 \\
\hline Other respiratory disease & 10 & 2 & & 16 & 20 & & 26 & 22 & 37 \\
\hline Medicine for the elderly: & 18 & 10 & 38 & 82 & 16 & 62 & 100 & 26 & 100 \\
\hline Respite care & 18 & 2 & & 0 & 0 & & 18 & 2 & 8 \\
\hline Neurological disorders & 0 & 4 & & 15 & 4 & & 15 & 8 & 31 \\
\hline Respiratory symptoms & 0 & 0 & & 14 & 6 & & 14 & 6 & 23 \\
\hline Malignant disease & 0 & 2 & & 4 & 0 & & 4 & 2 & 8 \\
\hline Gastrointestinal disorders & 0 & 0 & & 5 & 1 & & 5 & 1 & 4 \\
\hline Renal disease & 0 & 0 & & 2 & 0 & & 2 & 0 & \\
\hline Investigation of weight loss & 0 & 0 & & 1 & 1 & & 1 & 1 & 4 \\
\hline Ischaemic heart disease & 0 & 0 & & 15 & 0 & & 15 & 0 & \\
\hline Other acute illness & 0 & 0 & & 26 & 2 & & 26 & 2 & 8 \\
\hline Vascular disease & 0 & 2 & & 0 & 2 & & 0 & 4 & 15 \\
\hline General surgery: & 53 & 132 & 57 & 47 & 100 & 43 & 100 & 232 & 100 \\
\hline Major abdominal surgery & 14 & 12 & & 11 & 17 & & 25 & 29 & 12 \\
\hline Oesophageal surgery & 4 & 9 & & 2 & 0 & & 6 & 9 & 4 \\
\hline Minor surgical procedures & 10 & 59 & & 7 & 36 & & 17 & 95 & 41 \\
\hline Other major surgery: & 16 & 18 & & 2 & 15 & & 18 & 33 & 14 \\
\hline Vascular surgery & 8 & 9 & & 6 & 8 & & 14 & 17 & 7 \\
\hline Surgical emphysema & 0 & 0 & & 1 & 0 & & 1 & 0 & \\
\hline Urological procedures/surgery/renal colic & 0 & 24 & & 2 & 14 & & 2 & 38 & 16 \\
\hline Pancreatic disease & 0 & 1 & & 4 & 0 & & 4 & 1 & 0.4 \\
\hline Abdominal pain & 1 & 0 & & 12 & 4 & & 13 & 4 & 2 \\
\hline Investigations for gastrointestinal bleeding & 0 & 0 & & 0 & 6 & & 0 & 6 & 3 \\
\hline Orthopaedic surgery & 43 & 6 & 11 & 57 & 47 & 89 & 100 & 53 & 100 \\
\hline Metastatic bone disease & 6 & 2 & & 0 & 0 & & 6 & 2 & 4 \\
\hline Trauma fractures & 0 & 0 & & 47 & 33 & & 47 & 33 & 62 \\
\hline Joint replacements & 19 & 0 & & 0 & 0 & & 19 & 0 & \\
\hline Minor surgical procedures & 18 & 3 & & 10 & 4 & & 28 & 7 & 13 \\
\hline Neurological observations & 0 & 0 & & 0 & 7 & & 0 & 7 & 13 \\
\hline Investigations joint pain & 0 & 1 & & 0 & 3 & & 0 & 4 & 8 \\
\hline
\end{tabular}

*McWhirter \& Pennington (1994).

against the high-specification portable scales) or if not possible ( $n$ 50) weight was calculated using calf circumference, knee height, mid-arm circumference and subscapular skinfold thickness using the equations of Steinbaugh (Chumlea et al. 1987). BMI (weight $(\mathrm{kg}) /$ height $(\mathrm{m})^{2}$ ) was calculated and was used to grade patients into normal weight, overweight and obese. Mid-arm and calf circumferences were measured with a plastic insertion tape measure, and skinfold thickness measurements were made with Holtain skinfold callipers (Crymmych, Wales, UK), according to standard techniques (World Health Organization, 1995). Mid-arm circumference and triceps skinfold thickness were used to calculate mid-arm muscle circumference (mid-arm muscle circumference $(\mathrm{cm})=$ mid-arm circumference - triceps skinfold thickness $\times 0.314$ ) (World Health Organization, 1995). As in the Scottish study 
(McWhirter \& Pennington, 1994), the values obtained for patients aged 16-64 years were compared with American published reference tables (Bishop et al. 1981) while the values obtained for the elderly population were compared to Welsh reference data (Burr \& Phillips, 1984). Our data were also compared to other published anthropometric reference material for the UK (BMI and mid-arm circumference) (Gregory et al. 1990) and Irish (BMI) (Lee \& Cunningham, 1990) populations where these exist. Weight loss before admission to hospital was calculated from either recalled weight or from measurements recorded on a previous hospital visit. Functional status was measured with a hand-grip dynamometer (Takai Scientific Instruments Ltd, Tokyo, Japan). The highest of three readings made with the non-dominant arm was used.

\section{Statistics}

Statistical analysis was carried out using the Statistical Package for the Social Sciences for Windows, version 6.0.1 (SPSS UK Ltd, Woking, Surrey, UK). $\chi^{2}$ analysis was used to test for differences between groups and to identify associations between unintentional weight loss before admission and undernutrition on admission. Independent sample $t$ tests were used to test for differences in mean BMI, muscle and fat stores between the Dublin patients and published data from Edinburgh, Scotland, UK (Bannerman et al. 1997) and South Wales, UK (Burr \& Phillips, 1984). Spearman's correlation was calculated to test the association between arm and calf muscle circumferences, between triceps and subscapular skinfold thickness measurements and between hand-grip strength on admission to hospital and weight loss before admission. $P$ values of less than 0.05 were considered to indicate statistical significance.

\section{Results}

\section{Body mass index}

Of the 569 patients analysed on admission, sixty-two (11\%) were undernourished, a considerably lower proportion than the $40 \%$ reported from Dundee. There was no difference in the prevalence of undernutrition between seasons (summer, $n$ 269; winter, $n$ 300) $(P=0 \cdot 39)$, males ( $n$ 318) and females
( $n$ 251) $(P=0 \cdot 97)$, higher $(n$ 132) and lower ( $n$ 437) socioeconomic groups $(P=0.55)$ and those aged equal to and above $(n 218)$ or below $(n 351) 65$ years $(P=0.53)$.

A BMI of $20-24.9 \mathrm{~kg} / \mathrm{m}^{2}$ was recorded in $225(40 \%)$, $25-29.9 \mathrm{~kg} / \mathrm{m}^{2}$ in $179(31 \%)$ and $30 \mathrm{~kg} / \mathrm{m}^{2}$ or more in eighty-eight $(15 \%)$ subjects. A BMI below $20 \mathrm{~kg} / \mathrm{m}^{2}$ was recorded in seventy-seven $(13.5 \%)$ patients, $18-20 \mathrm{~kg} / \mathrm{m}^{2}$ in forty-nine $(9 \%), 16-18 \mathrm{~kg} / \mathrm{m}^{2}$ in twenty-one $(4 \%)$ and below $16 \mathrm{~kg} / \mathrm{m}^{2}$ in seven $(1 \%)$. The use of BMI as the sole determinant of undernutrition (i.e. disregarding triceps skinfold thickness or mid-arm muscle circumference measurements) gave a higher prevalence of undernutrition (13.5\%) than when the additional anthropometric measurements were also considered.

Direct comparison by speciality between Dublin and Dundee shows a lower prevalence of undernutrition in each patient group (Table 2) and a higher prevalence of overweight and obesity in Dublin $(P<0.001)$ (Table 3$)$. In addition, the severity of undernutrition was less in Dublin with more normally nourished $(P<0.001)$ or mildly undernourished $(P<0 \cdot 001)$. Despite these overall differences, the prevalence of overweight and obesity among respiratory and general surgical patients was similar in both centres.

Mean BMI in the patient group was similar to that of the healthy subjects measured in the Irish National Nutrition Survey (Lee \& Cunningham, 1990). In Dublin patients aged over 75 years, females had significantly lower $(P<0 \cdot 05)$ and males had a trend towards lower $(P=0.05)$ mean BMI than their community-based Edinburgh counterparts. BMI for both male and female Dublin patients aged 65 years or more was similar to healthy males and females from South Wales (Table 4).

\section{Anthropometric measures of body composition}

A triceps skinfold thickness below the 5th percentile was found in twenty (3\%) Dublin patients while eighty-three $(15 \%)$ were between the 5 th and 15 th percentiles. A midarm muscle circumference value below the 5th percentile was found in sixty-four (11\%) Dublin patients with 131 $(23 \%)$ between the 5th and 15th percentile. Fewer Dublin than Dundee patients aged 16-64 years had a mid-arm circumference less than $25 \mathrm{~cm}(P<0.001)$ (Table 5). In all patients aged over 75 years in Dublin, mid-arm muscle

Table 2. Comparison of prevalence of undernutrition at admission between Dublin, Republic of Ireland and Dundee, Scotland, UK*

\begin{tabular}{|c|c|c|c|c|c|c|}
\hline & \multicolumn{3}{|c|}{ Dublin } & \multicolumn{2}{|c|}{ Dundee } & \multirow{3}{*}{$\begin{array}{c}\text { Statistical } \\
\text { significance† }\end{array}$} \\
\hline & \multicolumn{2}{|c|}{ No. undernourished } & \multirow[t]{2}{*}{ No. assessed } & \multirow[t]{2}{*}{ No. undernourished } & \multirow[t]{2}{*}{ No. assessed } & \\
\hline & $n$ & $\%$ & & & & \\
\hline General medicine & 25 & 13 & 198 & 46 & 100 & $P<0.001$ \\
\hline General surgery & 17 & 7 & 232 & 27 & 100 & $P<0.001$ \\
\hline Respiratory medicine & 11 & 18 & 60 & 45 & 100 & $P<0.01$ \\
\hline Medicine for the elderly & 4 & 15 & 26 & 43 & 100 & $P<0.05$ \\
\hline Orthopaedic surgery & 5 & 9 & 53 & 39 & 100 & $P<0.001$ \\
\hline
\end{tabular}

${ }^{*}$ McWhirter \& Pennington (1994).

$\dagger \chi^{2}$ analysis. 
Table 3. Distribution of nutritional status at time of admission to hospital in Dundee, Scotland, UK* and Dublin, Republic of Ireland

\begin{tabular}{|c|c|c|c|c|c|c|c|c|c|c|c|}
\hline \multirow[b]{3}{*}{ Hospital speciality } & \multirow{3}{*}{$\begin{array}{l}\text { Total } \\
(n)\end{array}$} & \multicolumn{6}{|c|}{ Undernutrition } & \multirow{2}{*}{\multicolumn{2}{|c|}{ Normal weight }} & \multirow{2}{*}{\multicolumn{2}{|c|}{$\begin{array}{l}\text { Overweight/ } \\
\text { obese }\end{array}$}} \\
\hline & & \multicolumn{2}{|c|}{ Mild } & \multicolumn{2}{|c|}{ Moderate } & \multicolumn{2}{|c|}{ Severe } & & & & \\
\hline & & $n$ & $\%$ & $n$ & $\%$ & $n$ & $\%$ & $n$ & $\%$ & $n$ & $\%$ \\
\hline \multicolumn{12}{|l|}{ General medicine: } \\
\hline Dublin & 198 & 17 & 9 & 7 & 4 & 1 & 0.5 & 90 & 45 & 83 & 42 \\
\hline Dundee & 100 & 11 & & 27 & & 8 & & 30 & & 24 & \\
\hline \multicolumn{12}{|l|}{ General surgery: } \\
\hline Dublin & 232 & 10 & 4 & 7 & 3 & 0 & & 96 & 41 & 119 & 51 \\
\hline Dundee & 100 & 10 & & 16 & & 1 & & 25 & & 48 & \\
\hline \multicolumn{12}{|c|}{ Respiratory medicine: } \\
\hline Dublin & 60 & 8 & 13 & 0 & & 3 & 5 & 26 & 43 & 23 & 38 \\
\hline Dundee & 100 & 13 & & 19 & & 13 & & 17 & & 38 & \\
\hline \multicolumn{12}{|c|}{ Medicine for the elderly: } \\
\hline Dublin & 26 & 4 & 15 & 0 & & 0 & & 11 & 42 & 11 & 42 \\
\hline Dundee & 100 & 4 & & 20 & & 19 & & 27 & & 30 & \\
\hline \multicolumn{12}{|c|}{ Orthopaedic surgery: } \\
\hline Dublin & 53 & 4 & 7 & 0 & & 1 & 2 & 23 & 43 & 25 & 47 \\
\hline Dundee & 100 & 28 & & 5 & & 6 & & 30 & & 31 & \\
\hline
\end{tabular}

${ }^{*}$ McWhirter \& Pennington (1994).

Table 4. BMI of Dublin, Republic of Ireland, hospitalised patients compared with Irish National Nutrition Survey, Edinburgh, Scotland, UK and South Wales, UK, data*

(Mean values and standard deviations)

\begin{tabular}{|c|c|c|c|c|c|c|c|c|c|c|c|}
\hline \multirow{2}{*}{$\begin{array}{l}\text { Age group } \\
\text { (years) }\end{array}$} & \multicolumn{3}{|c|}{ Dublin patients } & \multicolumn{3}{|c|}{ Irish National Nutrition Survey } & \multicolumn{3}{|c|}{ Edinburgh } & \multicolumn{2}{|c|}{ South Wales } \\
\hline & Mean & SD & $n$ & Mean & SD & $n$ & Mean & SD & $n$ & Mean & $n$ \\
\hline \multicolumn{12}{|l|}{ Men } \\
\hline $16-18$ & $21 \cdot 1$ & 1.4 & 5 & 21.2 & 2.5 & 73 & & & & & \\
\hline $18-25$ & 23.9 & 4.2 & 35 & $23 \cdot 1$ & $3 \cdot 1$ & 51 & & & & & \\
\hline $25-40$ & $25 \cdot 5$ & $5 \cdot 3$ & 68 & $26 \cdot 0$ & $3 \cdot 2$ & 85 & & & & & \\
\hline $40-60$ & $26 \cdot 0$ & 4.9 & 81 & $27 \cdot 3$ & $3 \cdot 1$ & 87 & & & & & \\
\hline$\geqslant 60$ & $25 \cdot 0$ & 4.4 & 129 & $25 \cdot 6$ & 3.8 & 82 & & & & & \\
\hline $75-79$ & 24.4 & 4.6 & 24 & & & & $26 \cdot 4$ & 3.5 & 31 & 23.9 & 188 \\
\hline $80-84$ & $23 \cdot 8$ & 4.9 & 13 & & & & $25 \cdot 9$ & $2 \cdot 6$ & 18 & $23 \cdot 7$ & 87 \\
\hline$\geqslant 85$ & 23.5 & $4 \cdot 2$ & 5 & & & & 24.5 & $4 \cdot 1$ & 10 & $23 \cdot 1$ & 41 \\
\hline \multicolumn{12}{|l|}{ Women } \\
\hline $16-18$ & $22 \cdot 8$ & 5.5 & 4 & $21 \cdot 7$ & $2 \cdot 7$ & 110 & & & & & \\
\hline $18-25$ & $23 \cdot 8$ & $4 \cdot 6$ & 18 & $23 \cdot 2$ & 3.0 & 54 & & & & & \\
\hline $25-40$ & 24.6 & 4.0 & 40 & 24.2 & 4.7 & 122 & & & & & \\
\hline $40-60$ & $26 \cdot 1$ & $5 \cdot 7$ & 59 & $26 \cdot 6$ & $4 \cdot 3$ & 111 & & & & & \\
\hline$\geqslant 60$ & $24 \cdot 8$ & 5.5 & 130 & $26 \cdot 4$ & 4.9 & 84 & & & & & \\
\hline $75-79$ & $24 \cdot 1$ & 4.0 & 32 & & & & $26 \cdot 2$ & 4.7 & 66 & $26 \cdot 1$ & 329 \\
\hline $80-84$ & $23 \cdot 8$ & 5.5 & 20 & & & & $26 \cdot 8$ & $4 \cdot 6$ & 32 & $25 \cdot 5$ & 200 \\
\hline$\geqslant 85$ & 22.5 & 3.5 & 11 & & & & 24.9 & 3.8 & 30 & $23 \cdot 6$ & 88 \\
\hline
\end{tabular}

* Lee \& Cunningham (1990), Bannerman et al. (1997) and Burr \& Phillips (1984) respectively.

Table 5. Distribution of mid-arm circumference in people aged 16-64 in Dublin, Republic of Ireland, hospitalised patients compared with data from Dundee, Scotland, UK and the general UK population*

\begin{tabular}{|c|c|c|c|c|c|c|c|c|c|c|c|c|}
\hline \multirow[b]{3}{*}{ Mid-arm circumference $(\mathrm{cm})$} & \multicolumn{6}{|c|}{ Men } & \multicolumn{6}{|c|}{ Women } \\
\hline & \multicolumn{2}{|c|}{$\begin{array}{l}\text { Dublin patients } \\
\qquad(\text { (n 214) }\end{array}$} & \multicolumn{2}{|c|}{$\begin{array}{l}\text { Dundee patients } \\
\qquad(n \text { 134) }\end{array}$} & \multicolumn{2}{|c|}{$\begin{array}{l}\text { UK population } \\
\quad(n \text { 1191) }\end{array}$} & \multicolumn{2}{|c|}{$\begin{array}{l}\text { Dublin patients } \\
\qquad(n \text { 137) }\end{array}$} & \multicolumn{2}{|c|}{$\begin{array}{l}\text { Dundee patients } \\
\qquad(n \text { 90) }\end{array}$} & \multicolumn{2}{|c|}{$\begin{array}{l}\text { UK populatior } \\
\text { ( } n \text { 1187) }\end{array}$} \\
\hline & $n$ & $\%$ & $n$ & $\%$ & $n$ & $\%$ & $n$ & $\%$ & $n$ & $\%$ & $n$ & $\%$ \\
\hline$<25$ & 20 & 9 & 29 & 22 & 36 & 3 & 26 & 19 & 28 & 31 & 167 & 14 \\
\hline $25 \cdot 1-27 \cdot 5$ & 43 & 20 & 35 & 26 & 167 & 14 & 33 & 24 & 17 & 19 & 320 & 27 \\
\hline $27 \cdot 6-30$ & 46 & 21.5 & 19 & 14 & 333 & 28 & 33 & 24 & 17 & 19 & 320 & 27 \\
\hline $30 \cdot 1-32.5$ & 59 & 28 & 27 & 20 & 369 & 31 & 19 & 14 & 8 & 9 & 202 & 17 \\
\hline$>32.5$ & 46 & 21.5 & 24 & 18 & 286 & 24 & 26 & 19 & 20 & 22 & 178 & 15 \\
\hline
\end{tabular}

${ }^{*}$ McWhirter \& Pennington (1994) and Gregory et al. (1990) respectively. 
circumferences were higher than in healthy people from South Wales $(P<0.05)$, but lower than recently reported from Edinburgh $(P<0 \cdot 05)$. Triceps skinfold thickness measurements in both male $(P<0.01)$ and female $(P<$ $0.05)$ patients in Dublin were higher than expected from the Welsh data, although they were similar to those found in Edinburgh (Table 6).

Calf circumference and subscapular skinfold thickness measurements were recorded in this study as additional measures of body composition. A significant correlation was observed between calf circumference and mid-arm muscle circumference $(r \quad 0.59, P<0.001)$ and between subscapular and triceps skinfold thickness measurements $(r 0.6, P<0 \cdot 001)$.

\section{Weight loss on admission}

Unintentional weight loss of over $10 \%$ in the 6 months before admission occurred in sixty-four $(12 \%$ of the 538 patients for whom data on previous weight were obtained) patients by comparison with $13 \%$ in the Dundee study (McWhirter \& Pennington, 1994). A further twenty-nine (5\%) patients had unintentional weight loss of more than $5 \%$ in the month before admission. Of the sixty-two undernourished patients, twenty-one (37\%) lost more than $10 \%$ body weight over the previous 6 months while a further nine (16\%) lost more than $5 \%$ over the previous month. Undernutrition on admission was significantly associated with unintentional weight loss over the 6 months before admission $(P<0 \cdot 001)$.

\section{Functional status on admission}

The grip strength of 523 patients was measured. A similar percentage of patients in both the Dublin and Dundee studies recorded a hand-grip strength below $85 \%$ of standard (Webb et al. 1989) (69\% v. $67 \%$ ). Highly significant negative correlations between hand-grip strength on admission to hospital and weight loss over both the 6 months $(r 0.19, P<0.001)$ and the 1 month $(r 0.18, P<0.001)$ before admission were observed. Of 218 patients reassessed before discharge, it was possible to measure hand-grip strength in 191. In the undernourished and high-nutritionalrisk groups, a significantly higher proportion of patients who lost weight in hospital lost hand-grip strength in comparison to those in the same groups who gained weight $(P<0 \cdot 05)$.

\section{Changes in nutritional status during hospital stay}

Table 7 shows details of the weight changes for the 202 patients in whom BMI could be calculated both on admission and on discharge. The median length of stay for these patients was $12 \mathrm{~d}$. Weight loss occurred in $65 \%$ of overweight and obese (median length of stay $11 \mathrm{~d}$ ), $66 \%$ of normal weight (median length of stay $13 \mathrm{~d}$ ) and $43 \%$ of underweight patients (median length of stay $15 \mathrm{~d}$ ). Weight gain occurred in $31 \%$ of overweight and obese, $30 \%$ of normal weight and $43 \%$ of underweight patients. None of the undernourished patients moved into a worse category of the three categories of undernutrition (mild, moderate, severe). Two normal weight (BMI $20-24.9 \mathrm{~kg} / \mathrm{m}^{2}$ ) patients became

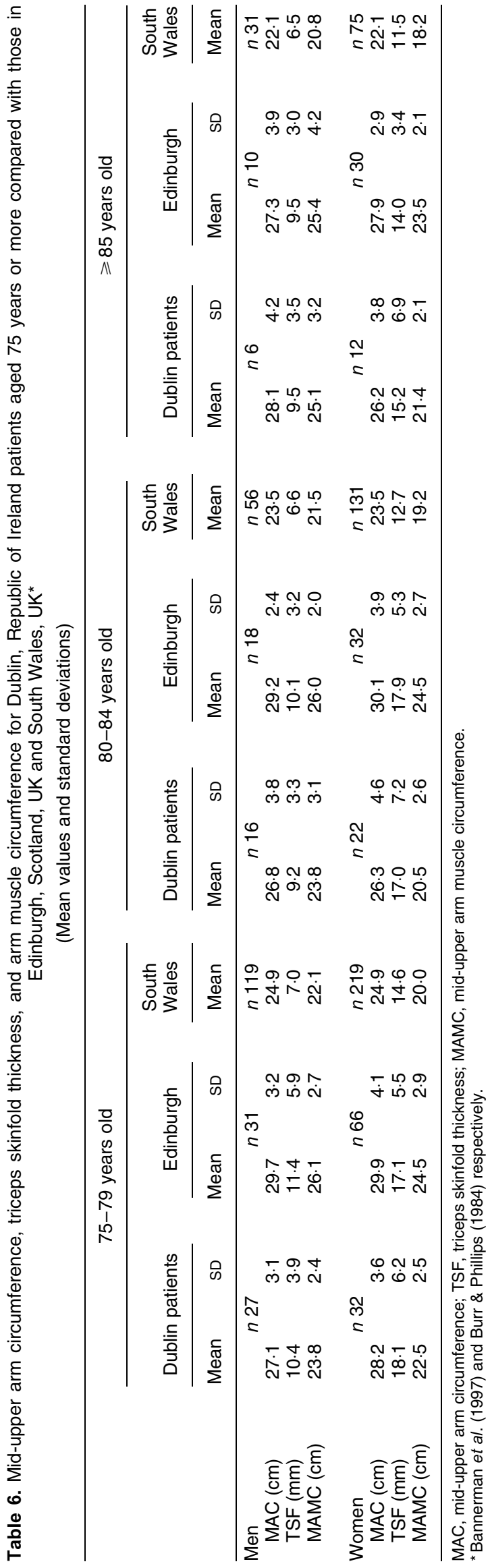


Table 7. Changes in weight during the hospital stay in 202 Dublin, Republic of Ireland patients who were reassessed on discharge

Patient's status on admission

\begin{tabular}{|c|c|c|c|c|c|c|c|c|c|c|c|}
\hline & & & & & \multicolumn{7}{|c|}{ Undernourished } \\
\hline & \multicolumn{2}{|c|}{$\begin{array}{l}\text { Overweight } \\
\text { (n 91) }\end{array}$} & \multicolumn{2}{|c|}{$\begin{array}{l}\text { Normal } \\
(n \text { 88) }\end{array}$} & \multicolumn{2}{|c|}{$\begin{array}{l}\text { Mild } \\
(n 16)\end{array}$} & \multicolumn{2}{|c|}{$\begin{array}{l}\text { Moderate } \\
\text { (n 5) }\end{array}$} & \multicolumn{2}{|c|}{$\begin{array}{l}\text { Severe } \\
(n 2)\end{array}$} & \multirow{2}{*}{$\begin{array}{c}\begin{array}{c}\text { Number referred } \\
(n \text { 12) }\end{array} \\
n\end{array}$} \\
\hline & $n$ & $\%$ & $n$ & $\%$ & $n$ & $\%$ & $n$ & $\%$ & $n$ & $\%$ & \\
\hline No change & 4 & 4 & 4 & 5 & 2 & 12 & 1 & 20 & 0 & & 0 \\
\hline Weight loss & 59 & 65 & 58 & 66 & 7 & 44 & 2 & 40 & 1 & 50 & 6 \\
\hline Weight gain & 28 & 31 & 26 & 29 & 7 & 44 & 2 & 40 & 1 & 50 & 6 \\
\hline
\end{tabular}

mildly underweight $\left(\right.$ BMI $<20 \mathrm{~kg} / \mathrm{m}^{2}$ and mid-arm muscle circumference or triceps skinfold thickness below the 15th percentile), six obese patients (BMI $30-39.9 \mathrm{~kg} / \mathrm{m}^{2}$ ) became overweight (BMI $25-29.9 \mathrm{~kg} / \mathrm{m}^{2}$ ) and seven overweight patients became normal weight. Of the twenty-three undernourished patients (BMI below $20 \mathrm{~kg} / \mathrm{m}^{2}$ and mid-arm muscle circumference or triceps skinfold thickness below the 15 th percentile) reassessed on discharge, twelve (52\%) were referred for nutritional support. Six of these patients gained weight while six lost weight from time of admission to discharge.

\section{Discussion}

Using identical criteria to define undernutrition, our present study found that $11 \%$ of patients admitted to hospital in Dublin were undernourished by comparison with $40 \%$ in a similar study in Dundee (McWhirter \& Pennington, 1994). The reasons for the difference are not clear but a number of possibilities must be considered. First, the case-mix of patients may be different. The diagnoses and nature of admissions for both Dublin and Dundee can be seen in Table 1. While the case-mix of two such studies can never be identical, with the exception of the general surgical group where admission for minor surgical procedures was more common in Dublin, and admission for abdominal pain higher in Dundee, the mix within each patient group is similar. While the Dublin study included more surgical patients who were certainly better nourished than their counterparts in Dundee, if only medical patients had been considered, the prevalence of undernutrition among such patients ( $n$ 284) was only $15 \%$, significantly lower than the $45 \%$ among medical patients $(n$ 100) in Dundee. The Dublin study included sixty patients in respiratory medicine by comparison with 100 in the Dundee study. Prevalence of undernutrition was $18 \%$ in Dublin v. $45 \%$ in Dundee. It is unlikely that if a further forty respiratory patients were assessed, thirty-four would be undernourished. The same principle applies to orthopaedic surgical patients where only $9 \%$ of patients in Dublin v. $39 \%$ in Dundee were undernourished. The differences in case-mix are unlikely to account for the discrepancy in results, particularly when the prevalence of undernutrition is compared within diagnostic categories. Indeed, malignant disease occurred more frequently in all diagnostic categories (with the exception of general surgery) in Dublin than in Dundee. Although only twenty-six patients admitted under Medicine for the Elderly were assessed in Dublin, 40\% ( $n$ 218) of the total patient group were aged 65 years or more. There was no difference in the prevalence of undernutrition occurring in patients aged under 65-years or in those aged 65 years or more in this study $(P=0.53)$, or in the Dundee study $(43 \%$ in patients admitted under Medicine for the Elderly $v$. an overall prevalence of $40 \%$ ). The proportion of elective and non-elective patients admitted to each speciality can also be seen in Table 1. Although it could be postulated that differences between numbers of elective and non-elective admissions could account for the difference in prevalence of undernutrition, it is unlikely to account for a $29 \%$ disparity between the two studies. Indeed, medical, respiratory, orthopaedic and elderly patients admitted acutely are in general sicker, and therefore one would expect, more undernourished than their counterparts admitted for elective procedures.

Second, there is a possibility that Scottish and/or UK patients are different in some way from Irish patients. Undoubtedly, while there is a significantly greater proportion of patients admitted to hospital in Dundee with a BMI below $20 \mathrm{~kg} / \mathrm{m}^{2}$, this has not been observed in other, more recent, studies carried out in Scotland and the UK. The Scottish study (Tessier et al. 2000) reported that $13 \%$ of 219 patients admitted to hospital in Glasgow were undernourished on admission (defined as a BMI below $18.5 \mathrm{~kg} / \mathrm{m}^{2}$ or $18.5-20 \mathrm{~kg} / \mathrm{m}^{2}$ with reported weight loss greater than $3 \mathrm{~kg}$ in 3 months). Two studies from London reported that $16.5 \%$ of 410 general medical, general surgical and orthopaedic patients (Vlaming et al. 1999) and 22\% of 192 general medical admissions (Weekes, 1999) had a BMI below $20 \mathrm{~kg} / \mathrm{m}^{2}$ on admission while a study from Manchester (Strain et al. 1999) reported that $24 \%$ of 400 medical, surgical and orthopaedic patients who were expected to be in hospital for at least 1 week (therefore choosing those who were sickest on admission) were undernourished according to the criteria of McWhirter \& Pennington (1994; BMI below $20 \mathrm{~kg} / \mathrm{m}^{2}$ and mid-arm muscle circumference or triceps skinfold thickness below the 15th percentile). It is widely accepted that rates of undernutrition in nursing homes and institutions are broadly comparable to those found in hospital. The recent UK National Diet and Nutrition Survey (Finch et al. 1998) reported that $16 \%$ of men and $15 \%$ of women living in institutions were underweight, an identical figure to that found in Dublin among those admitted under Medicine for the Elderly (Table 2) and to all elderly patients ( $n$ 218) admitted in Dublin (16\%). It could be postulated that a unique situation exists in Dundee and 
that the figure of $40 \%$ undernutrition found there is not representative of rates in other parts of the UK and Republic of Ireland. One possible explanation for this could be that the normal anthropometric profile in the Dundee population is different to that found more usually in the UK and Republic of Ireland. The recent data from the UK (Finch et al. 1998) and from our group (Corish et al. 2000) show that for those aged 65 years and over, the anthropometric profile for the healthy elderly is identical in both countries. Although not all patients are in this age group, $40 \%$ of the Dublin patients and $55 \%$ of those in Dundee were elderly, and as stated previously, differences in the prevalence of undernutrition between the younger and older age groups were not observed in either study. That the normal anthropometric profile is different in Dundee is supported by the fact that in both studies, a similar percentage of patients reported weight loss of more than $10 \%$ in the 6 months before admission to hospital (12\% in Dublin v. $13 \%$ in Dundee) and suffered functional impairment as indicated by a hand-grip strength less than $85 \%$ of the reference data (Webb et al. 1989) (69\% in Dublin v. $67 \%$ in Dundee). If patients in Dundee have to wait longer for hospital admission and are, therefore, presumably sicker on admission it is highly probable that recent weight loss and functional impairment would be observed to a far higher degree there compared with Dublin. The possibility that the population of Dundee has a lower distribution of BMI is supported by another Scottish study. This study from Edinburgh (Bannerman et al. 1997), using the same criteria as McWhirter \& Pennington (1994), could find no undernutrition among 200 elderly patients ( $\geqslant 75$ years) registered with two general practices. Given that $43 \%$ of patients admitted under Medicine for the Elderly are undernourished on admission to hospital in Dundee and therefore, must become undernourished while still living at home, it is surprising that none of the 200 elderly people in Edinburgh were found to be undernourished when assessed in their own homes which allowed for the inclusion of those too ill to attend the clinic or the general practitioner.

Although we cannot dispute the differences in the proportion of patients with a BMI below $20 \mathrm{~kg} / \mathrm{m}^{2}$ in Dublin and Dundee, we have to query the current applicability of such a cut-off for clinical purposes in most centres in the UK and Republic of Ireland. Selective catabolic loss of protein due to infection or injury causes extreme illness in overweight patients who lose muscle whilst still retaining substantial amounts of total body and subcutaneous fat (Ferro-Luzzi \& James, 1996). Such selective loss of lean tissue was observed in this study. Although only $18 \%$ of patients had a triceps skinfold thickness below the 15th percentile, $34 \%$ had a mid-arm muscle circumference below this value. It is therefore probable that these patients are more undernourished than indicated by the measurement of BMI and fat stores. The prevalence of obesity is increasing in Republic of Ireland (Lee \& Cunningham, 1990; Kilkenny Health Project, 1992), the UK (Prentice \& Jebb, 1995; Jebb, 1999) and the USA (Galuska et al. 1996; Van Itallie, 1996; Flegal et al. 1998). We know that the mean BMI for the healthy elderly population in both the UK and Republic of Ireland is $26.7 \mathrm{~kg} / \mathrm{m}^{2}$ (Finch et al. 1998; Corish et al. 2000). The shift in the distribution of anthropometric data could lead to significant biases when used for assessing the nutritional status of patients on admission to hospital if the normal healthy local population from which these patients come is getting fatter, and the average and percentile lines for anthropometric measures are changing. Although we know that the pragmatic cut-off values for BMI are based on physiological and medical correlates, weight loss is also associated with undernutrition-related complications, particularly if it occurs with functional impairment, regardless of pre-illness weight (Haydock \& Hill, 1986). Furthermore, there is little information in older age groups as to the appropriateness of a cut off value of $20 \mathrm{~kg} / \mathrm{m}^{2}$ to define undernutrition in this age group. With the secular increase in adult BMI, the cut-off values at which patients are considered to be at nutritional risk may have to be altered and in the elderly in the USA, nutritional risk is now defined as a BMI below $24 \mathrm{~kg} / \mathrm{m}^{2}$ while a BMI less than $22 \mathrm{~kg} / \mathrm{m}^{2}$ was observed to be a significant predictor of mortality in older Italian people living in the community (Landi et al. 1999). Significantly more elderly patients with an average BMI of $20.9 \mathrm{~kg} / \mathrm{m}^{2}$ who were undergoing lungvolume reduction surgery required ventilatory support and had significantly longer hospital length of stay than those patients with an average BMI of $26 \cdot 1 \mathrm{~kg} / \mathrm{m}^{2}$ (Mazolewski et al. 1999). The definition of undernutrition in both the Dundee and Dublin studies included triceps skinfold thickness or mid-arm muscle circumference measurements in addition to the BMI cut-off of $20 \mathrm{~kg} / \mathrm{m}^{2}$. These had to fall below the 15 th percentile compared to reference data in routine use in the UK and Republic of Ireland (Bishop et al. 1981; Burr \& Phillips, 1984). The secular changes observed in the anthropometric distribution of the population obviously will change where the 15 th percentile lies and define a different proportion of patients as undernourished compared to the use of the older reference data. A population shift in anthropometric variables has also recently been reported in infants in the UK (Paul et al. 1998; Savage et al. 1999) who conclude that there is a need for new reference data sets for head circumference and skinfold thickness for infants in the UK.

Anthropometric screening has been recommended for the detection of undernutrition in hospital and in the community as it is simple, cheap and non-invasive (McWhirter \& Pennington, 1994; World Health Organization, 1995; Edington et al. 1996, 1997). Its use however, requires reference data. These data are used both by nutritional epidemiologists, for monitoring secular changes in populations, and for making cross-country comparisons between population, and by clinicians for assessing nutritional status among ill individuals, either in hospital, or at hospital or community clinic visits. The reference data routinely used in the UK and Republic of Ireland are over 20 years old and derived from the USA population for younger adults and from South Wales for the elderly. We know that these data are significantly different from current anthropometric data on the elderly (Bannerman et al. 1997; Finch et al. 1998; Corish et al. 2000). The current reference data are therefore useful for monitoring trends in the population but their use as a tool in clinical practice must be addressed. The small number of undernourished individuals in Dublin and the high mortality rate in this group $(6.5 \%$ v. $2 \%$ in the adequately 
nourished group, $(P=0 \cdot 05))$ suggest that the criteria used identified patients whose underlying disease had progressed to the point where nutritional intervention could no longer be of therapeutic benefit. If we state that there is a genuinely lower level of undernutrition in Dublin, we must then assume that few patients will benefit from nutritional intervention, as in general, studies have demonstrated benefits only in undernourished patients (Bastow et al. 1983; Delmi et al. 1990; Veterans Affairs Total Parenteral Nutrition Cooperative Study Group, 1991; Beattie et al. 1999) with benefits not being observed in well-nourished patients (Heslin et al. 1997; Watters et al. 1997). However, we also know that pre-operative weight loss is associated with increased post-operative complications (Studley, 1936; Klidjian et al. 1980; Meguid et al. 1988; Reilly et al. 1988; Windsor \& Hill, 1988; Von Meyenfeldt et al. 1992) which can result in longer post-operative convalescence times (Bastow et al. 1983; Lumbers et al. 1996), increased duration of hospital stay (Bastow et al. 1983; Shaw-Stiffel et al. 1993) and increased post-operative mortality (Busby et al. 1980; Giner et al. 1996). It is obviously not necessary and uneconomical for all patients to receive nutritional intervention. It is equally unsatisfactory if patients who would benefit from nutritional intervention do not receive it. It is therefore necessary that outcome data should be considered among those falling at the lower end of the population distribution curve for a particular population to assess the potential benefits for this group from nutritional intervention.

Weight loss in hospital occurred as frequently in Dublin as in Dundee (63\% v. $64 \%$ of patients lost weight). However, the mean weight loss was less in Dublin than in Dundee ( $4 \%$ v. $6 \%)$. Weight loss also occurred less frequently in the undernourished group in Dublin $(43 \% v$. $75 \%)(P<0.05)$. Referral for nutritional intervention occurred in $20 \%$ of patients in Dublin including $40 \%$ of the undernourished patients. In Dundee, only $18 \%$ of the undernourished group were referred. The higher referral rate in Dublin may either reflect better nutritional practice in Dublin, or the fact that, in response to earlier studies such as that of McWhirter \& Pennington (1994), there is generally a greater awareness with more referrals as a consequence. It is difficult to draw conclusions without historical data on referral rates in Dublin.

Nutritional status on admission to hospital is thought to be an important factor in determining clinical outcome. It has been argued that nutrition screening on admission to hospital is worthwhile to identify those who would benefit most from nutrition intervention (Lennard-Jones, 1992; Reilly et al. 1995). However, there is no clear definition of undernutrition or nutritional risk. Anthropometry provides a simple method of assessing nutritional status for this purpose, but in order to assess patients in the clinical setting knowledge of the normal anthropometric status of the local healthy population may be necessary. Although, we can certainly say that fewer patients in Dublin than in Dundee are undernourished using the current reference data and threshold levels, the changing anthropometric profile of the normal population in both the UK and Republic of Ireland means that this may not tell the full story. A review of the anthropometric criteria to assess nutritional status on admission to hospital is, therefore, mandatory. We need to have agreement on the most appropriate anthropometric thresholds to decide which patients in the clinical setting are at risk. Other variables (e.g. weight loss, loss of lean tissue and/or functional impairment) should also be fully evaluated and recommendations made as to how they should be incorporated into the definition of undernutrition. Complacency on the basis of these results from Dublin could result in many patients not receiving nutritional intervention who could benefit from it.

\section{Acknowledgement}

This work was supported by a studentship from Abbott Laboratories Limited, Dublin, Republic of Ireland.

\section{References}

Bannerman E, Reilly JJ, MacLennon WJ, Kirk T \& Pender F (1997) Evaluation of validity of British anthropometric reference data for assessing nutritional state of elderly people in Edinburgh: cross sectional study. British Medical Journal 315, 338-341.

Bastow MD, Rawlings J \& Allison SP (1983) Benefits of supplementary tube feeding after fractured neck of femur: a randomised controlled trial. British Medical Journal 287, 1589-1592.

Beattie AH, Baxter JP, Prach AT \& Pennington CR (1999) An evaluation of the use of enteral nutritional supplements post operatively in malnourished surgical patients. Proceedings of the Nutrition Society 58, 112A.

Bishop CW, Bowen PE \& Ritchley SI (1981) Norms for nutritional assessment of American adults by upper arm anthropometry. American Journal of Clinical Nutrition 34, 2530-2539.

Bistrian BR, Blackburn GL, Vitale J, Cochran D \& Naylor J (1976) Prevalence of malnutrition in general medical patients. Journal of the American Medical Association 253, 1567-1570.

Burr ML \& Phillips KM (1984) Anthropometric norms in the elderly. British Journal of Nutrition 51, 165-169.

Busby GP, Mullen JL, Mathews DC, Hobbs CL \& Rosato EF (1980) Prognostic nutritional index in gastrointestinal surgery. American Journal of Surgery 139, 160-167.

Butterworth CE (1974) The skeleton in the hospital closet. Nutrition Today 9, 4-8.

Chumlea WC, Roche AF \& Steinbaugh ML (1985) Estimating stature from knee height for persons 60-90 years of age. Journal of the American Geriatric Society 33, 116-120.

Chumlea WC, Roche AF \& Mukherjee D (1987) Nutritional Assessment of the Elderly through Anthropometry. Columbus, $\mathrm{OH}$ : Ross Laboratories.

Coats KG, Morgan SL, Bartolucci AA \& Weinsier RL (1993) Hospital-associated malnutrition: a re-evaluation 12 years later. Journal of the American Dietetic Association 93, 27-33.

Corish C, Flood P \& Kennedy NP (2000) Anthropometric data of healthy elderly Irish subjects. Proceedings of the Nutrition Society (In the Press).

Delarue J, Constans T, Malvy D, Pradignac A, Court C \& Lamas F (1994) Anthropometric values in an elderly French population. British Journal of Nutrition 71, 295-302.

Delmi M, Rapin C-H, Bengoa J-M, Delmas PD, Vasey H \& Bonjour J-P (1990) Dietary supplementation in elderly patients with fractured neck of femur. Lancet 335, 1013-1016.

Edington J, Kon P \& Martyn CN (1996) Prevalence of malnutrition in general practice. Clinical Nutrition 15, 60-63.

Edington J, Kon P \& Martyn CN (1997) Prevalence of malnutrition after major surgery. Journal of Human Nutrition and Dietetics 10, 111-116. 
Ferro-Luzzi A \& James WPT (1996) Adult malnutrition: simple assessment techniques for use in emergencies. British Journal of Nutrition 75, 3-10.

Finch S, Doyle W, Lowe C, Bates CJ, Prentice A, Smithers G \& Clarke PC (1998) National Diet and Nutrition Survey: People Aged 65 Years and Over. Volume 1: Report of the Diet and Nutrition Survey. London: The Stationery Office.

Flegal KM, Carroll MD, Kuczmarski RJ \& Johnson CL (1998) Overweight and obesity in the United States: prevalence and trends, 1960-1994. International Journal of Obesity Related Metabolic Disorders 22, 39-47.

Frisancho AR (1981) New norms of upper limb fat and muscle areas for assessment of nutritional status. American Journal of Clinical Nutrition 34, 2540-2545.

Gallagher-Allred CR, Coble Voss C, Finn SC \& McCamish MA (1996) Malnutrition and clinical outcomes: the case for medical nutrition therapy. Journal of the American Dietetic Association 96, 361-366, 369.

Galuska DA, Serdula M, Pamuk E, Siegel PZ \& Byers T (1996) Trends in overweight among US adults from 1987 to 1993: a multistate telephone survey. American Journal of Public Health 86, 1729-1735.

Gariballa SE, Parker SG, Taub N \& Castleden M (1998) Nutritional status of hospitalized acute stroke patients. British Journal of Nutrition 79, 481-487.

Giner M, Laviano A, Meguid MM \& Gleason JR (1996) In 1995 a correlation between malnutrition and poor outcome still exists. Nutrition 12, 23-29.

Gregory J, Foster K, Tyler H \& Wiseman M (1990) The Dietary and Nutritional Survey of British Adults. London: The Stationery Office.

Haydock DA \& Hill GL (1986) Impaired wound healing in surgical patients with varying degrees of malnutrition. Journal of Parenteral and Enteral Nutrition 10, 550-554.

Heslin MJ, Latkany L, Leung D, Brooks AD, Hochwald SN, Pisters PWT, Shike M \& Brennan MF (1997) A prospective randomised trial of early enteral feeding after resection of upper gastrointestinal malignancy. Annals of Surgery 226, 567-580.

Hill GL, Blackett RL, Pickford I, Birkenshaw L, Young GA, Warren JB, Schorah CG \& Morgan DB (1977) Malnutrition in surgical patients: an unrecognised problem. Lancet i, 689692.

Jebb SA (1999) Obesity: from molecules to man. Proceedings of the Nutrition Society 58, 1-14.

Kilkenny Health Project (1992) A Pilot Programme for Coronary Heart Disease Prevention in Ireland 1985-1990. Kilkenny: Kilkenny Health Project.

Klidjian AM, Foster KJ, Kammerling RM, Cooper A \& Karran SJ (1980) Relation of anthropometric and dynamometric variables to serious postoperative complications. British Medical Journal 281, 899-901.

Landi F, Zuccala G, Gambassi G, Incalzi RA, Manigrasso L, Pagano F, Carbonin P \& Bernabei R (1999) Body mass index and mortality among older people living in the community. Journal of the American Geriatric Society 47, 1072-1076.

Launer LJ \& Harris T (1996) Weight, height and body mass index distributions in geographically and ethnically diverse samples of older persons. Age and Ageing 25, 300-306.

Lee P \& Cunningham K (1990) Irish National Nutrition Survey. Dublin: Irish Nutrition and Dietetic Institute.

Lennard-Jones JE (1992) A Positive Approach to Nutrition as a Treatment. London: Kings Fund Centre.

Lumbers M, Driver LT, Howland RJ, Older MWJ \& Williams CM (1996) Nutritional status and clinical outcome in elderly female surgical orthopaedic patients. Clinical Nutrition 15, $101-107$.
McWhirter JP \& Pennington CR (1994) Incidence and recognition of malnutrition in hospital. British Medical Journal 308, 945948.

Mazolewski P, Turner JF, Baker M, Kurtz T \& Little AG (1999) The impact of nutritional status on the outcome of lung volume reduction surgery: a prospective study. Chest 116, 693-696.

Meguid MM, Campos ACL, Meguid V, Debonis D \& Terz JJ (1988) IONIP, a criterion of surgical outcome and patient selection for perioperative nutrition support. British Journal of Clinical Practice 63, 8-14.

Naber THJ, Schermer T, de Bree A, Nusteling K, Eggink L, Kruimel JW, Bakkeren J, van Heereveld H \& Katan MB (1997) Prevalence of malnutrition in nonsurgical hospitalized patients and its association with disease complications. American Journal of Clinical Nutrition 66, 1232-1239.

Norgan NG (1994) Population differences in body composition in relation to the body mass index. European Journal of Clinical Nutrition 48, 10S-25S.

Paul AA, Cole TJ, Ahmed EA \& Whitehead RG (1998) The need for revised standards for skinfold thickness in infancy. Archives of Disease in Childhood 78, 354-358.

Prentice AM \& Jebb SA (1995) Obesity in Britain: gluttony or sloth? British Medical Journal 311, 437-439.

Rea IM, Gillen S \& Clarke E (1997) Anthropometric measurements from a cross-sectional survey of community dwelling subjects aged over 90 years of age. European Journal of Clinical Nutrition 51, 102-106.

Reilly JJ, Hull SF, Albert N, Waller A \& Bringardener S (1988) Economic impact of malnutrition: a model system for hospitalised patients. Journal of Parenteral and Enteral Nutrition 12, 371-376.

Reilly HM, Martineau JK, Moran A \& Kennedy H (1995) Nutritional screening-evaluation and implementation of a simple nutrition risk score. Clinical Nutrition 14, 269-273.

Savage SAH, Reilly JJ, Edwards CA \& Durnin JVGA (1999) Adequacy of standards for assessment of growth and nutritional status in infancy and early childhood. Archives of Disease in Childhood 80, 121-124.

Shaw-Stiffel TA, Zarney LA, Pleban WE, Rosman DD, Rudolf RA \& Bernstein LH (1993) Effect of nutrition status and other factors on length of hospital stay after major gastrointestinal surgery. Nutrition 9, 140-145.

Stack JA, Babineau TJ \& Bistrian BR (1996) Assessment of nutritional status in clinical practice. The Gastroenterologist $\mathbf{4}$, $8 \mathrm{~S}-15 \mathrm{~S}$.

Strain NC, Wright CE, Ward K \& Shaffer JL (1999) Can the true prevalence of malnutrition be assessed on admission to hospital? Proceedings of the Nutrition Society 58, 112A.

Studley HO (1936) Percentage of weight loss. A basic indicator of surgical risk in patients with chronic peptic ulcer. Journal of the American Medical Association 106, 458-460.

Tessier S, Kelly IE, Cahill A, Morris SE, Crumley A, Mclaughlin D, McKee RF \& Lean MEJ (2000) Still hungry in hospital: identifying malnutrition in acute hospital admissions. Proceedings of the Nutrition Society (In the Press).

Tucker HN \& Miguel SG (1996) Cost containment through nutrition intervention. Nutrition Reviews 54, 111-121.

Van Itallie TB (1996) Prevalence of obesity. Endocrinology and Metabolism Clinics of North America 25, 887-905.

Veterans Affairs Total Parenteral Nutrition Co-operative Study Group (1991) Perioperative total parenteral nutrition in surgical patients. New England Journal of Medicine 325, 525-532.

Vlaming S, Biehler A, Chattopadhyay S, Jamieson C, Cunliffe A \& Powell-Tuck J (1999) Nutritional status of patients on admission to acute services of a London teaching hospital. Proceedings of the Nutrition Society 58, 119A. 
Von Meyenfeldt MF, Meijerink WJHJ, Rouflart MMJ, BuilMaassen NTHJ \& Soeters PB (1992) Perioperative nutritional support: a randomised clinical trial. Clinical Nutrition 11, 180186.

Watters JM, Kirkpatrick SM, Norris SB, Shamji FM \& Wells GA (1997) Immediate postoperative enteral feeding results in impaired respiratory mechanics and decreased mobility. Annals of Surgery 226, 369-380.

Webb AE, Newman LA, Taylor M \& Keogh JB (1989) Hand grip dynamometry as a predictor of post operative complications. Re-appraisal using age standardised grip strengths. Journal of Parenteral and Enteral Nutrition 13, 30-33.

Weekes E (1999) The incidence of malnutrition in medical patients admitted to a hospital in south London. Proceedings of the Nutrition Society 58, 126A.

Windsor JA \& Hill GL (1988) Weight loss with physiologic impairment. A basic indicator of surgical risk. Annals of Surgery 205, 290-296.

World Health Organization (1995) Physical Status: The Use and Interpretation of Anthropometry. World Health Organization Technical Report no. 854. Geneva: WHO.

Zemel BS, Riley EM \& Stallings VA (1997) Evaluation of methodology for nutritional assessment in children: anthropometry, body composition, and energy expenditure. Annual Reviews in Nutrition 17, 211-235. 